\title{
Analisis Perilaku dan Faktor Penyebab Perilaku Penggunaan Antibiotik Tanpa Resep di Surabaya
}

\section{Behavior Analysis and Attributed Factors to Non Prescription Antibiotic Used in Surabaya}

\author{
Dewi Paskalia Andi Djawaria ${ }^{1}$, Adji Prayitno Setiadi2,3*, Eko Setiawan ${ }^{2,3}$ \\ ${ }^{1}$ Program Magister Ilmu Farmasi, Universitas Surabaya, Surabaya 60293, Indonesia \\ ${ }^{2}$ Departemen Farmasi Klinis dan Komunitas, Fakultas Farmasi, Universitas Surabaya \\ ${ }^{3}$ Pusat Informasi Obat dan Layanan Kefarmasian (PIOLK), Fakultas Farmasi, Universitas \\ Surabaya \\ ('adji_ps@hotmail.com)
}

\begin{abstract}
ABSTRAK
Perilaku dan faktor dominan penyebab penggunaan antibiotik tanpa resep di Surabaya belum diketahui secara pasti. Tujuan penelitian ini adalah untuk mengidentifkasi perilaku dan faktor yang paling mempengaruhi penggunaan antibiotik tanpa resep. Penelitian dengan desain potong lintang dilakukan pada masyarakat yang membeli antibiotik tanpa resep dokter di 90 apotek di Surabaya selama bulan Desember 2014-April 2015. Identifikasi perilaku dilakukan melalui 8 pertanyaan majemuk, dan identifikasi faktor dilakukan melalui dua metode statistik, yakni analisis deskriptif melalui perbandingan mean pertanyaan dalam masing-masing tema faktor, dan analisis faktor menggunakan orthogonal rotation (varimax). Total 267 responden terlibat dalam penelitian. Mayoritas masyarakat yang membeli antibiotik tanpa resep dokter berusia 21-30 tahun (36,33\%), membeli dengan frekuensi $1 \mathrm{kali} /$ bulan $(45,70 \%)$, membeli untuk diri sendiri $(56,55 \%)$, membeli segera setelah gejala muncul $(33,70 \%)$, membeli untuk indikasi pilek/flu (21,30\%). Berdasarkan hasil uji statistik deskriptif ditemukan bahwa tema "halhal yang mendorong" merupakan faktor yang mempengaruhi penggunaan antibiotik tanpa resep di apotek. Pada metode analisis faktor, nilai cumulative percent total variance explained adalah sebesar 48,03\%, dengan nilai terbesar pada faktor pertama yakni sebesar $23,91 \%$. Faktor paling mempengaruhi penggunaan antibiotik tanpa resep adalah kemudahan akses memperoleh antibiotik dan penghematan biaya. Hasil penelitian ini dapat digunakan untuk menentukan metode intervensi yang tepat untuk menanggulangi permasalahan penggunaan antibiotik tanpa resep di apotek. Dengan mempertimbangkan kompleksitas faktor penyebab perilaku tersebut, apoteker tidak seharusnya dituduh sebagai satu-satunya pihak penyebab penggunaan antibiotik tanpa resep.
\end{abstract}

Kata kunci : Antibiotik, apoteker komunitas, obat tanpa resep

\section{ABSTRACT}

There is limited information regarding the behavior and determinant factors of non-prescribed use of antibioticsin Surabaya. The purpose of this study was to identify the behavior and the most influential factors in using antibiotics without prescription. This was a cross sectional studyconducted insubjects who bought antibiotics without prescription in 90 pharmacies in Surabaya during December 2014-April 2015. Eight complex questions were used to identify the behavior. The contributing factors of non-prescription behavior were identified by using two statistical methods, including: descriptive analysis by comparing the mean of the questions in each factor theme, and factor analysis using orthogonal rotation (varimax). There were 267 respondents involved in this study. The majority of respondents who bought antibiotics without prescription ranged from age 21-30 years old $(36.33 \%)$, frequency buying antibiotics $1 /$ month (45.70\%), intended for themselves (56.55\%), buying antibiotics soon after the symptoms appeared (33.70\%), and intended for runny noselfu indication $(21.30 \%)$. Based on the descriptive statistic, the theme "aspects that encourage" was found as the factor contributed to the use of antibiotics without prescription. The value of cumulative percent total variance found in the factor analysis method explained was $48.03 \%$, with the biggest value on the first factor that was $23.91 \%$. The most influential factor was the ease of access to get the antibiotics and the saving of money. The results of this study can be used to determine the appropriate intervention to deal with the use of antibiotics without prescription in the pharmacies. Considering the complex causes of such behavior, pharmacist should not be blamed as the only cause of non-prescribed use of antibiotics.

Keywords: Antibiotics, community pharmacist, non-presribed use of medicine 


\section{PENDAHULUAN}

Penyakit infeksi merupakan salah satu masalah kesehatan yang seringkali menyebabkan pasien mencari pertolongan tenaga kesehatan. Data dari Amerika Serikat menunjukkan bahwa penyakit infeksi menyebabkan 27,1 juta kunjungan pasien ke praktek dokter pada tahun 2009 dan 3,2 juta kunjungan rawat jalan rumah sakit pada tahun 2010. ${ }^{1,2}$ Tingginya jumlah penyakit infeksi di dunia menyebabkan antibiotik menjadi salah satu obat yang paling banyak digunakan. Data dari European Centre for Disease Prevention and Control (ECDC) pada tahun 2010 menunjukkan konsumsi antibiotik untuk pemakaian non-topikal di komunitas berkisar antara 11,1-34,9 defined daily dose (DDD)/1.000 jiwa per hari. ${ }^{3,4}$

Salah satu permasalahan terkait penggunaan antibiotik di komunitas adalah penggunaan antibiotik tanpa resep dokter dan fenomena tersebut merupakan masalah kesehatan global. ${ }^{5-10}$ Beberapa penelitian di negara berkembang menunjukkan tingginya penggunaan antibiotik tanpa resep dokter. ${ }^{9,10}$ Permasalahan penggunaan antibiotik tanpa resep dokter juga terjadi di Indonesia. ${ }^{11}$ Bukti penelitian dengan setting Indonesia terkait penggunaan antibiotik tanpa resep dokter didapatkan dari penelitian yang dilakukan oleh Widayati et al. Penelitian yang dilakukan terhadap 559 responden menunjukkan bahwa terdapat $324(58,00 \%)$ responden berniat melakukan swamedikasi dengan antibiotik. ${ }^{11}$ Prevalensi penggunaan antibiotik tanpa resep selama 1 bulan terakhir adalah 7,30\%. ${ }^{11}$ Bukti-bukti penelitian terpublikasi baik di setting Indonesia maupun non-Indonesia mempertegas tingginya frekuensi penggunaan antibiotik tanpa resep dokter secara global yang apabila tidak segera dikendalikan dapat menyebabkan konsekuensi yang lebih berbahaya bagi dunia kesehatan secara global.

Penggunaan antibiotik tanpa resep dokter berpotensi menimbulkan berbagai macam risiko antara lain: 1) peningkatan jumlah kasus infeksi yang disebabkan bakteri patogen yang resisten; 2) peningkatan risiko terjadinya kejadian obat yang tidak dikehendaki (adverse drug events); 3) penurunan efektivitas terapi, dan 4) peningkatan biaya kesehatan. ${ }^{12-17}$ Resistensi mikroorganisme penyebab infeksi terhadap antibiotik merupakan salah satu risiko paling besar yang perlu diwaspa- dai. Pada praktek penggunaan antibiotik tanpa resep dokter, antibiotik yang digunakan umumnya adalah antibiotik dengan spektrum luas seperti golongan penisilin dan sefalosporin yang hingga saat ini direkomendasikan penggunaannya sebagai antibiotik lini pertama untuk mengatasi berbagai infeksi di rumah sakit.9-11,18,19 Peningkatan penggunaan antibiotik lini pertama tersebut terbukti meningkatkan temuan kasus infeksi oleh patogen yang resistensi terhadap antibiotik lini pertama. Data dari World Health Organization (WHO) menyatakan bahwa resistensi terhadap antibiotik lini pertama, mengharuskan penggunaan antibiotik lini berikutnya yang seringkali lebih mahal harganya. ${ }^{20}$ Data tersebut perlu menjadi catatan penting bagi pemerintah Indonesia yang telah mengimplementasikan sistem Jaminan Kesehatan Nasional (JKN). Selain konsekuensi dari perspektif ekonomi, peningkatan penggunaan antibiotik lini lanjutan secara berulang, berpotensi meningkatkan risiko resistensi terhadap antibiotik tersebut. Risiko resistensi terhadap antibiotik lini lanjutan perlu mendapat perhatian serius dari berbagai pihak khususnya pemerintah dengan mempertimbangkan lambatnya laju penemuan antibiotik dibandingkan laju resistensinya. ${ }^{21}$ Apabila tidak segera mendapatkan intervensi yang tepat, bukan hal yang mustahil peradaban manusia akan terancam oleh serangan kasus infeksi yang tidak bisa disembuhkan.

Intervensi yang efektif dan efisien perlu dilakukan untuk memperbaiki perilaku penggunaan antibiotik secara swamedikasi di apotek. Sebagai upaya untuk menghasilkan intervensi yang efektif dan efisien perlu dilakukan penggalian faktor-faktor yang mempengaruhi penggunaan antibiotik tanpa resep di apotek. Sampai saat ini belum terdapat bukti penelitian terpublikasi yang memetakan faktor utama yang menyebabkan masyarakat Indonesia menggunakan antibiotik tanpa resep dokter. Tanpa data tersebut, dikhawatirkan akan dihasilkan metode intervensi yang tidak tepat sasaran. Tujuan penelitian ini adalah melihat perilaku dan menentukan faktor yang paling mempengaruhi penggunaan antibiotik tanpa resep dokter pada setting komunitas, yakni apotek, di Kota Surabaya. 


\section{BAHAN DAN METODE}

Proses analisis faktor penyebab perilaku pembelian antibiotik tanpa resep dokter dilakukan dengan menggunakan kuesioner yang telah valid dan reliabel. ${ }^{22}$ Proses pengembangan kuesioner dan uji validasi serta reliabilitas kuesioner dapat dilihat pada artikel yang telah terpublikasi tersebut. ${ }^{22}$ Kuesioner yang digunakan dalam penelitian ini terdiri dari dua (2) bagian utama, yakni: bagian pertama yang bertujuan untuk memetakan perilaku penggunaan antibiotik tanpa resep dokter di apotek (terdiri dari delapan pertanyaan dengan pilihan jawaban manjemuk) dan bagian kedua yang bertujuan untuk mengidentifikasi faktor penyebab penggunaan antibiotik tanpa resep dokter (terdiri dari 14 pertanyaan rating). ${ }^{22}$ Nilai Cronbach's $\mathrm{Al}$ pha untuk bagian kedua kuesioner adalah $0,883 .{ }^{22}$ Total terdapat 5 tema faktor penyebab penggunaan antibiotik tanpa resep dokter yang dipetakan dalam 14 pertanyaan bagian kedua, yakni: 1) persepsi dan perilaku penggunaan antibiotik oleh pasien; 2) hal-hal yang mendorong penggunaan antibiotik tanpa resep dokter; 3) hal-hal yang mencegah penggunaan antibiotik tanpa resep dokter; 4) personil yang mendorong/memfasilitasi penggunaan antibiotik tanpa resep dokter; 5) aspek legal.

Responden dalam penelitian ini adalah pasien dewasa yang membeli antibiotik tanpa resep dokter di apotek. Proses identifikasi responden dilakukan secara purposive kepada setiap pasien yang membeli antibiotik tanpa resep dokter di apotek. Proses pemilihan apotek sebagai lokasi penelitian dilakukan melalui proses randomisasi. Data apotek yang diperoleh dari Dinas Kesehatan Provinsi Jawa Timur digunakan sebagai sampling frame dalam penelitian ini. Kriteria eksklusi yang dikenakan pada saat pemilihan apotek adalah apotek yang berada di rumah sakit, klinik kecantikan, praktek dokter bersama, dan klinik pengobatan. Penentuan apotek yang menjadi lokasi penyebaran kuesioner dilakukan dengan menggunakan metode simple random sampling dengan menggunakan $t a b$ le of random numbers.

Pemilihan responden penelitian dilakukan secara purposive sampling, yakni dengan memberikan kuesioner kepada pengunjung apotek yang diketahui membeli antibiotik tanpa resep dokter pada saat tim peneliti melakukan kunjungan ke apotek. Sebanyak 2-4 masyarakat yang membe- li antibiotik tanpa resep dokter per-apotek pada saat tim peneliti melakukan kunjungan ke apotek diambil sebagai responden penelitian. Proses randomisasi dengan menggunakan responden yang dalam hal ini adalah pembeli antibiotik tanpa resep dokter tidak dapat dilakukan karena ketiadaan sampling frame. Kesediaan responden untuk ikut serta dalam penelitian dibuktikan dengan mengisi informed consent. Proses perizinan terhadap pemilik sarana apotek dilakukan sebelum menyebarkan kuesioner.

Jumlah apotek yang menjadi lokasi penelitian dihitung dengan menggunakan rumus Slovin. ${ }^{23}$ Data dari Dinas Kesehatan (Dinkes) Provinsi Jawa Timur tahun 2013 menunjukkan bahwa terdapat 855 apotek di Kota Surabaya. Penghitungan besar sampel dalam penelitian ini adalah sebagai berikut: ${ }^{23}$

$$
\begin{aligned}
& n-\frac{N}{i+n e x}
\end{aligned}
$$

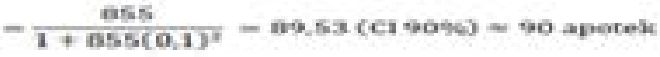

Keterangan : $n=$ jumlah sampel; $\mathrm{N}=$ jumlah populasi; $e=$ batas toleransi kesalahan, dalam perhitungan ini digunakan batas toleransi kesalahan sebesar $10 \%$.

Berdasarkan lokasi, apotek dari data Dinkes Provinsi Jawa Timur tersebut kemudian dikategorikan ke dalam lima wilayah Kota Surabaya, yaitu: Surabaya Timur, Surabaya Selatan, Surabaya Barat, Surabaya Utara, dan Surabaya Pusat. Jumlah apotek pada masing-masing wilayah yang digunakan sebagai sampel diambil secara proporsional dengan perhitungan sebagai berikut:

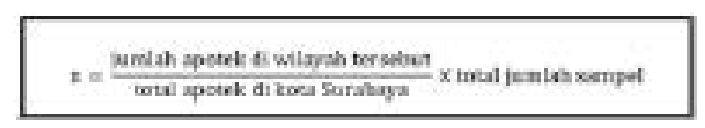

Keterangan : $\mathrm{n}=$ jumlah apotek per wilayah

Berdasarkan hasil perhitungan tersebut, detail jumlah apotek tempat pengambilan sampel untuk masing-masing wilayah adalah sebagai berikut: 37 apotek di Surabaya Timur, 21 apotek di Surabaya Selatan, 10 apotek di Surabaya Pusat, 13 apotek di Surabaya Barat, dan 9 apotek di Surabaya Utara.

Analisis jawaban pertanyaan rating dilakukan melalui dua metode, yakni metode analisis deskriptif melalui perbandingan mean pertanyaan dalam masing-masing domain faktor dan metode 
analisis faktor. Domain faktor dengan mean paling besar dianggap sebagai domain faktor yang paling dominan mempengaruhi perilaku penggunaan antibiotik tanpa resep dokter. Analisis deskriptif terhadap lima domain faktor dilakukan untuk memberikan gambaran besar domain dalam Theory of Planned Behaviour yang dominan berkontribusi terhadap perilaku penggunaan antibiotik tanpa resep dokter.

Analisis faktor (factor analysis) dilakukan dengan metode orthogonal rotation (varimax). Cut-off point untuk nilai $\mathrm{R}$ yang dianggap memenuhi syarat dalam analisis faktor adalah $\geq 0,400$. Kesesuaian jumlah sampel untuk dianalisis dengan menggunakan analisis faktor ditunjukkan melalui nilai Kaiser-Meyer-Olkin (KMO) measure of sample adequacy. Jumlah sampel dinyatakan sesuai untuk dianalisis dengan analisis faktor apabila nilai $\mathrm{KMO}>0,500$. Analisis faktor dilakukan terhadap 10 tema penyebab penggunaan antibiotik tanpa resep dokter. Dengan demikian, hasil analis faktor akan memberikan gambaran yang lebih detail dari analisis deskriptif. Analisis pertanyaan majemuk kuesioner dilakukan dengan menggunakan analisis data deskriptif yang digambarkan dengan perbandingan frekuensi pilihan jawaban yang paling sering muncul (modus). Keseluruhan proses ini dilakukan dengan menggunakan SPSS 20.0 .

\section{HASIL}

Total terdapat 267 responden yang terlibat dalam penelitian ini, 109 orang $(40,82 \%)$ pasien berjenis kelamin laki-laki dan 158 orang $(59,18 \%)$ pasien berjenis kelamin perempuan. Mayoritas responden yang ikut serta dalam penelitian berada pada rentang usia 21-30 tahun yaitu sebanyak 97 orang (36,33\%). Data karakteristik responden selengkapnya dapat dilihat pada Tabel 1.

Hasil analisis bagian pertama kuesioner, yakni delapan pertanyaan dengan jawaban majemuk pada kuesioner yang bertujuan untuk memetakan perilaku penggunaan antibiotik tanpa resep dokter di apotek dapat dilihat pada Tabel 2. Berdasarkan pertanyaan majemuk tersebut, diperoleh hasil bahwa 63 pasien $(23,60 \%)$ sering membeli antibiotik tanpa resep di apotek, 203 orang $(76,00 \%)$ jarang membeli antibiotik tanpa resep dokter di apotek, sedangkan satu pasien $(0,37 \%)$
Tabel 1. Karakteristik Responden Penelitian

\begin{tabular}{|c|c|c|}
\hline Karakteristik & $\mathrm{n}=\mathbf{2 6 7}$ & $\%$ \\
\hline \multicolumn{3}{|l|}{ Umur } \\
\hline 15-20 tahun & 29 & 10,86 \\
\hline 21-30 tahun & 97 & 36,33 \\
\hline $31-40$ tahun & 60 & 22,47 \\
\hline 41-50 tahun & 51 & 19,10 \\
\hline 51-60 tahun & 19 & 7,12 \\
\hline$>60$ tahun & 11 & 4,12 \\
\hline \multicolumn{3}{|l|}{ Jenis Kelamin } \\
\hline Laki-laki & 109 & 40,82 \\
\hline Perempuan & 158 & 59,18 \\
\hline \multicolumn{3}{|l|}{ Pendidikan } \\
\hline $\mathrm{SD} /$ sederajat & 6 & 2,25 \\
\hline $\mathrm{SMP} /$ sederajat & 12 & 4,49 \\
\hline SMA/sederajat & 125 & 46,82 \\
\hline Diploma/Strata 1 & 52 & 19,48 \\
\hline Pascasarjana & 6 & 2,25 \\
\hline NA & 66 & 24,71 \\
\hline \multicolumn{3}{|l|}{ Pekerjaan } \\
\hline Pelajar/mahasiswa & 31 & 11,61 \\
\hline Ibu rumah tangga & 26 & 9,74 \\
\hline Wiraswasta & 95 & 35,58 \\
\hline PNS/BUMN/ TNI-Polri & 5 & 1,87 \\
\hline Pekerja di bidang kesehatan & 8 & 3,00 \\
\hline Karyawan/karyawati & 20 & 7,48 \\
\hline Tidak bekerja & 1 & 0,37 \\
\hline Guru & 4 & 1,50 \\
\hline Kuli & 1 & 0,37 \\
\hline NA & 76 & 28,46 \\
\hline
\end{tabular}

NA : Not alvailable (responden tidak memberikan jawaban); SD: Sekolah Dasar; SMP: Sekolah Menegah Pertama; SMA: Sekolah Menegah Atas; PNS: Pegawai Negeri Sipil; BUMN: Pegawai Badan Usaha Milik Negara; TNI-Polri : Tentara Nasional Indonesia- Kepolisisan Republik Indonesia.

tidak menjawab pertanyaan ini. Sebanyak 122 pasien $(45,70 \%)$ membeli antibiotik dengan frekuensi $1 \mathrm{kali} / \mathrm{bulan}$, dan hanya 9 pasien $(3,40 \%)$ yang membeli antibiotik dengan frekuensi 2-3 kali/ minggu. Sebanyak 151 pasien (56,55\%) membeli antibiotik untuk diri sendiri dan 25 pasien $(9,36 \%)$ membeli antibiotik untuk orang lain.

Berdasarkan hasil uji statistik deskriptif terhadap 14 pertanyaan rating yang bertujuan untuk mengidentifikasi faktor penyebab penggunaan antibiotik tanpa resep dokter dapat dilihat pada Tabel 3 (detail pertanyaan untuk bagian kedua kuesioner tidak ditampilkan). Hasil analisis deskriptif tersebut menegaskan bahwa faktor yang dominan mempengaruhi perilaku pembelian antibiotik tanpa resep dokter adalah "hal-hal yang mendorong" 
Tabel 2a. Perilaku Pembelian Antibiotik Tanpa Resep Dokter di Apotek

\begin{tabular}{|c|c|c|c|}
\hline No. & Pertanyaan & $\mathbf{n}$ & $\%$ \\
\hline \multirow[t]{3}{*}{1} & Seberapa sering Bapak/Ibu membeli antibiotik tanpa resep dokter? & & \\
\hline & Jarang & 203 & 76,00 \\
\hline & Sering & 64 & 24,00 \\
\hline \multirow[t]{8}{*}{2} & Berapa kali Bapak/Ibu biasanya membeli antibiotik tanpa resep dokter? & & \\
\hline & 1x/bulan & 122 & 45,70 \\
\hline & $3 \mathrm{x} /$ bulan & 56 & 21,00 \\
\hline & $2 \mathrm{x} / \mathrm{bulan}$ & 27 & 10,10 \\
\hline & 1 $\mathrm{x} /$ minggu & 21 & 7,90 \\
\hline & $>3 \mathrm{x} /$ minggu & 15 & 5,60 \\
\hline & $2-3 \mathrm{kali} / \mathrm{minggu}$ & 9 & 3,40 \\
\hline & Tidak menjawab & 17 & 6,30 \\
\hline \multirow[t]{5}{*}{3} & Biasanya antibiotik yang saya beli tanpa resep dokter akan digunakan oleh : & & \\
\hline & Diri sendiri & 151 & 56,60 \\
\hline & Diri sendiri dan orang lain & 89 & 33,30 \\
\hline & Orang lain & 25 & 9.40 \\
\hline & Tidak menjawab & 2 & 0,70 \\
\hline \multirow[t]{8}{*}{4} & $\begin{array}{l}\text { Kapan Bapak/Ibu memutuskan untuk menggunakan antibiotik tanpa resep } \\
\text { dokter? }\end{array}$ & & \\
\hline & Segera setelah muncul gejala & 90 & 33,70 \\
\hline & Jika tidak kunjung sembuh & 77 & 28,84 \\
\hline & Jika gejala yang dirasakan cukup parah & 73 & 27,34 \\
\hline & Jika gejala cukup parah dan tidak kunjung sembuh* & 12 & 4,50 \\
\hline & Segera setelah munculnya gejala penyakit dan jika tidak kunjung sembuh* & 8 & 3,00 \\
\hline & $\begin{array}{l}\text { Segera setelah muncul gejala, jika gejala yang dirasakan cukup parah, jika } \\
\text { tidak kunjung sembuh* }\end{array}$ & 3 & 1,12 \\
\hline & Tidak menjawab & 4 & 1,50 \\
\hline \multirow[t]{14}{*}{5} & Antibiotik untuk penggunaan tanpa resep dokter diperoleh dari : & & \\
\hline & Apotek & 137 & 51,30 \\
\hline & Sisa dari resep dokter sebelumnya & 32 & 12,00 \\
\hline & Diberi oleh teman/keluarga & 24 & 9,00 \\
\hline & Apotek dan sisa dokter sebelumnya* & 20 & 7,50 \\
\hline & Apotek dan kios* & 14 & 5,20 \\
\hline & Apotek dan diberi oleh teman/keluarga* & 12 & 4,50 \\
\hline & Apotek, sisa resep dokter sebelumnya, diberi oleh teman/keluarga* & 8 & 3,00 \\
\hline & Kios & 7 & 2,60 \\
\hline & Sisa dari tetangga & 4 & 1,50 \\
\hline & Sisa dari resep dokter sebelumnya, diberi oleh teman/keluarga* & 3 & 1,10 \\
\hline & Lainnya & 1 & 0,40 \\
\hline & Semua pilihan jawaban** & 1 & 0,40 \\
\hline & Tidak menjawab & 4 & 1,50 \\
\hline
\end{tabular}

perilaku pembelian antibiotik tanpa resep. "Halhal yang mendorong" dalam penelitian ini adalah pengalaman penggunaan antibiotik sebelumnya, perilaku peresepan dokter, dan akses untuk memperoleh antibiotik. Faktor yang paling tidak dominan mempengaruhi perilaku pembelian antibiotik tanpa resep dokter adalah "faktor hal-hal yang mencegah perilaku pembelian antibiotik tanpa resep dokter di apotek". Faktor ini meliputi isu keamanan, efek samping, dan pengetahuan akan bahaya penggunaan antibiotik tanpa resep dokter di apotek.

Hasil analisis faktor terhadap 14 pertanyaan kuesioner dipaparkan secara detail pada Tabel 4. Hasil analisis dengan KMO measure of sampling adequacy menunjukkan nilai sebesar 0,749 . Nilai cumulative percent total variance explained adalah sebesar 48,03\%. Analisis faktor terhadap 14 
Tabel 2b. Perilaku Pembelian Antibiotik Tanpa Resep Dokter di Apotek

\begin{tabular}{|c|c|c|c|}
\hline No. & Pertanyaan & $\mathbf{n}$ & $\%$ \\
\hline \multirow[t]{25}{*}{6} & $\begin{array}{l}\text { Siapakah yang menyarankan Bapak/Ibu membeli antibiotik tanpa resep } \\
\text { dokter? }\end{array}$ & & \\
\hline & Teman/kerabat yang bekerja di bidang kesehatan & 65 & 24,30 \\
\hline & Keluarga & 56 & 21,00 \\
\hline & Tenaga kesehatan di apotek & 30 & 11,20 \\
\hline & Diri sendiri & 17 & 6,40 \\
\hline & Teman/kerabat yang tidak bekerja di bidang kesehatan & 12 & 4,50 \\
\hline & Keluarga dan tetangga* & 11 & 4,10 \\
\hline & Keluarga dan teman/kerabat yang tidak bekerja di bidang kesehatan & 11 & 4,10 \\
\hline & Keluarga dan tenaga kesehatan di apotek* & 10 & 3,70 \\
\hline & $\begin{array}{l}\text { Keluarga, teman/kerabat yang tidak bekerja di bidang kesehatan, teman/kerabat } \\
\text { yang bekerja di bidang kesehatan* }\end{array}$ & 10 & 3,70 \\
\hline & Tenaga kesehatan di apotek dan teman/kerabat yang bekerja di bidang kesehatan* & 9 & 3,40 \\
\hline & Keluarga, tetangga, teman/kerabat yang tidak bekerja di bidang kesehatan* & 5 & 1,90 \\
\hline & Tetangga & 5 & 1,90 \\
\hline & Keluarga, tenaga kesehata ndi apotek, tetangga* & 4 & 1,50 \\
\hline & Tetangga dan teman/kerabat yang bekerja di bidang kesehatan* & 3 & 1,10 \\
\hline & Keluarga dan teman/kerabat yang bekerja di bidang kesehatan* & 3 & 1,10 \\
\hline & Teman/kerabat yang bekerja dan tidak bekerja di bidang kesehatan* & 2 & 0,70 \\
\hline & Keluarga, tetangga, teman/kerabat yang tidak bekerja di bidang kesehatan* & 2 & 0,70 \\
\hline & Keluarga dan orang penting di desa & 1 & 0,40 \\
\hline & Orang penting di desa & 1 & 0,40 \\
\hline & Keluarga dan diri sendiri & 1 & 0,40 \\
\hline & Tetangga dan teman/kerabat yang tidak bekerja di bidang kesehatan* & 1 & 0,40 \\
\hline & Tetangga, teman/kerabat yang bekerja dan tidak bekerja di bidang kesehatan* & 1 & 0,40 \\
\hline & Tetangga, keluarga, teman/kerabat yang bekerja di bidang kesehatan* & 1 & 0,40 \\
\hline & Tidak menjawab & 6 & 2,20 \\
\hline \multirow[t]{10}{*}{7} & $\begin{array}{l}\text { Menurut saya, obat dalam resep dokter yang tidak saya butuhkan untuk } \\
\text { penyakit infeksi saya: }\end{array}$ & & \\
\hline & Vitamin & 133 & 49,80 \\
\hline & Anti nyeri & 47 & 17,60 \\
\hline & Penurun panas & 44 & 16,50 \\
\hline & Penurun panas dan anti nyeri* & 8 & 3,00 \\
\hline & Vitamin dan penurun panas* & 3 & 1,10 \\
\hline & Vitamin dan anti nyeri* & 3 & 1,10 \\
\hline & Vitamin, penurun panas, anti nyeri* & 2 & 0,70 \\
\hline & Antibiotik & 1 & 0,40 \\
\hline & Tidak menjawab & 26 & 9,70 \\
\hline \multirow[t]{17}{*}{8} & $\begin{array}{l}\text { Saya akan langsung membeli dan menggunakan antibiotik tanpa resep } \\
\text { apabila saya mengalami : }\end{array}$ & & \\
\hline & Pilek/flu & 57 & 21,30 \\
\hline & Demam & 53 & 19,90 \\
\hline & Batuk & 47 & 17,60 \\
\hline & Batuk dan pilek/flu* & 22 & 8,20 \\
\hline & Demam, pilek/flu, batuk* & 22 & 8,20 \\
\hline & Demam dan pilek/flu* & 14 & 5,20 \\
\hline & Radang tenggorokan & 11 & 4,10 \\
\hline & Nyeri & 10 & 3,70 \\
\hline & Sakit gigi & 7 & 2,60 \\
\hline & Infeksi & 5 & 1,90 \\
\hline & Luka/luka bakar & 2 & 0,70 \\
\hline & Demam dan batuk & 2 & 0,70 \\
\hline & Gatal-gatal & 1 & 0,40 \\
\hline & Sakit yang parah & 1 & 0,40 \\
\hline & Demam, sakit gigi, sakit perut & 1 & 0,40 \\
\hline & Tidak menjawab & 12 & 4,50 \\
\hline
\end{tabular}


Tabel 3. Karakteristik Responden Penelitian

\begin{tabular}{clc}
\hline No & \multicolumn{1}{c}{ Domain } & Mean \\
\hline 1 & $\begin{array}{l}\text { Persepsi dan perilaku penggunaan } \\
\text { antibiotik oleh pasien }\end{array}$ & 2,678 \\
2 & $\begin{array}{l}\text { Hal-hal yang mendorong penggunaan } \\
\text { antibiotik tanpa resep di apotek }\end{array}$ & 2,823 \\
3 & $\begin{array}{l}\text { Hal-hal yang mencegah penggunaan } \\
\text { antibiotik tanpa resep di apotek }\end{array}$ & 2,547 \\
4 & $\begin{array}{l}\text { Personel yang mendorong } \\
\text { penggunaan antibiotik tanpa resep } \\
\text { dokter di apotek }\end{array}$ \\
5 & Aspek legal & - \\
\hline
\end{tabular}

pertanyaan kuesioner (Tabel 4) menemukan 3 underlying factors yang mempengaruhi perilaku penggunaan antibiotik tanpa resep dokter, yaitu: 1) Kemudahan akses memperoleh antibiotik dan penghematan biaya (cumulative percent total variance explained sebesar 23,91\%), 2) Pengetahuan yang keliru terkait penggunaan/manfaat antibiotik (cumulative percent total variance explained sebesar 14,93\%), dan 3) Kurangnya pemahaman mengenai kompetensi dan kewenangan profesi tenaga kesehatan (cumulative percent total variance explained sebesar 9,19\%).

\section{PEMBAHASAN}

Penelitian ini merupakan penelitian yang mengeksplorasi faktor penyebab perilaku penggunaan antibiotik tanpa resep dokter di komunitas dari perspektif pengguna akhir antibiotik yang dalam hal ini adalah masyarakat yang melakukan praktek pembelian antibiotik tanpa resep. Terdapat sebuah penelitian yang menghitung jumlah apotek di Surabaya yang melayani pembelian antibiotik tanpa resep dokter. ${ }^{24}$ Puspitasari et al. menyatakan terdapat $90 \%$ dari 80 sampel apotek melayani pembelian antibiotik tanpa resep dokter. Tidak terdapat informasi penyebab perilaku dari sisi masyarakat sebagai pembeli antibiotik dalam penelitian tersebut. Tanpa adanya informasi terkait faktor penyebab masyarakat menggunakan antibiotik tanpa resep dokter, dikhawatirkan adanya kecenderungan untuk menyalahkan pekerja apotek sebagai aktor utama pencetus perilaku penggunaan antibiotik tanpa resep dokter. Kecenderungan tersebut akan memicu dihasilkannya intervensi yang dapat merugikan pekerja apotek dan tidak menyelesaikan akar permasalahan utama penyebab perilaku penggunaan antibiotik tanpa resep dokter. Oleh karena itu, informasi terkait perilaku dan penyebab masyarakat dalam menggunakan antibiotik tanpa resep dokter diharapkan dapat memungkinkan pihak-pihat terkait, termasuk pemerintah melakukan intervensi yang tepat pada pihak yang tepat.

Hasil penelitian ini menunjukkan bahwa sebanyak $58,80 \%$ pasien yang membeli antibiotik tanpa resep dokter di apotek berada pada rentang usia 21-40 tahun. Hasil ini serupa dengan hasil penelitian dari Abasaeed et al. dan Bin Nafisah et $a l .{ }^{10,25}$ Hasil penelitian yang dilakukan di Surabaya dan diperkuat dengan bukti-bukti terpublikasi tersebut menegaskan besarnya penggunaan antibiotik tanpa resep dokter oleh populasi pada rentang usia produktif. Salah satu pertimbangan kelompok usia produktif dalam menggunakan antibiotik tanpa resep dokter adalah efektivitas biaya. Penelitian Khan et al. di India terhadap 744 pasien usia produktif (18-50 tahun) menyatakan bahwa 88,00\% responden menggunakan antibiotik tanpa resep dokter karena merasa lebih efektif secara biaya. ${ }^{9}$ Efektivitas biaya dalam hal ini tidak hanya timbul karena penghematan biaya yang seharusnya dibutuhkan untuk mendapatkan layanan di pusat layanan kesehatan saja, tetapi juga karena dapat mencegah kemungkinan hilangnya produktivitas sebagai akibat sakit yang dialami. Penggunaan antibiotik tanpa resep dipersepsikan oleh masyarakat dapat mempercepat proses penyembuhan penyakit sehingga pasien tidak kehilangan banyak waktu untuk bekerja.

Mayoritas responden dalam penelitian ini menyatakan bahwa antibiotik tanpa resep dokter diperoleh dari apotek $(51,31 \%)$. Banyaknya warga Surabaya yang mendapatkan antibiotik dari apotek juga ditemukan di bagian Indonesia lain. Hasil penelitian oleh Widayati et al. di Yogyakarta yang menemukan bahwa $64,00 \%$ antibiotik untuk penggunaan tanpa resep diperoleh dari apotek. ${ }^{26}$ Program intervensi secara masal di Indonesia yang ditujukan untuk memperbaiki persepsi masyarakat awam terkait penggunaan antibiotik perlu dibuat. Salah satu program intervensi yang terbukti efektif mengendalikan penggunaan antibiotik tanpa resep dokter adalah program kampanye yang diprogramkan secara serentak dan sistematis di suatu negara. Program intervensi berupa kampanye serentak telah dilakukan di Perancis dan menunjukkan efekti- 
Tabel 4. Analisis Faktor Pembelian Antibiotik Tanpa Resep Dokter di Apotek

\begin{tabular}{|c|c|c|c|c|c|c|c|c|c|}
\hline \multicolumn{10}{|c|}{ Total Variance Explained } \\
\hline \multirow{2}{*}{$\begin{array}{l}\text { Compo- } \\
\text { nent }\end{array}$} & \multicolumn{3}{|c|}{ Initial Eigenvalues } & \multicolumn{3}{|c|}{$\begin{array}{c}\text { Extraction Sums of Squared } \\
\text { Loadings }\end{array}$} & \multicolumn{3}{|c|}{$\begin{array}{c}\text { Rotation Sums of Squared } \\
\text { Loadings }\end{array}$} \\
\hline & Total & $\begin{array}{c}\% \text { of } \\
\text { variance }\end{array}$ & $\begin{array}{c}\text { Cumulative } \\
\%\end{array}$ & Total & $\begin{array}{c}\% \text { of } \\
\text { variance }\end{array}$ & $\begin{array}{c}\text { Cumulative } \\
\%\end{array}$ & Total & $\begin{array}{c}\% \text { of } \\
\text { variance }\end{array}$ & $\begin{array}{c}\text { Cumulative } \\
\%\end{array}$ \\
\hline 1 & 3,347 & 23,907 & 23,907 & 3,347 & 23,907 & 23,907 & 2,847 & 20,337 & 20,337 \\
\hline 2 & 2,090 & 14,929 & 38,837 & 2,090 & 14,929 & 38,837 & 1,972 & 14,086 & 34,423 \\
\hline 3 & 1,288 & 9,198 & 48,034 & 1,288 & 9,198 & 48,034 & 1,906 & 13,611 & 48,034 \\
\hline 4 & 0,990 & 7,069 & 55,104 & & & & & & \\
\hline 5 & 0,940 & 6,717 & 61,820 & & & & & & \\
\hline 6 & 0,847 & 6,049 & 67,869 & & & & & & \\
\hline 7 & 0,769 & 5,492 & 73,361 & & & & & & \\
\hline 8 & 0,740 & 5,284 & 78,645 & & & & & & \\
\hline 9 & 0,674 & 4,817 & 83,462 & & & & & & \\
\hline 10 & 0,584 & 4,173 & 87,636 & & & & & & \\
\hline 11 & 0,536 & 3,828 & 91,463 & & & & & & \\
\hline 12 & 0,442 & 3,160 & 94,623 & & & & & & \\
\hline 13 & 0,416 & 2,970 & 97,594 & & & & & & \\
\hline 14 & 0,337 & 2,406 & 100,000 & & & & & & \\
\hline
\end{tabular}

Extraction Method: Principal Component Analysis

vitas dalam menurunkan jumlah peresepan antibiotik untuk gejala $f$ lu like syndrome sebesar $26,50 \%$ $(95 \% \mathrm{CI}=19,60 \%-33,50 \%)$ di seluruh wilayah Perancis dalam kurun waktu 5 tahun..$^{27}$ Kampanye serupa juga sedang dilakukan di Thailand, yang berdasarkan publikasi terakhir telah mencapai fase ke-3 yang bertujuan memperkuat kerjasama dan mencari cara untuk memperluas implementasi program intervensi. ${ }^{28}$ Melihat adanya kedekatan secara geologis, metode kampanye yang dilakukan di Thailand sangat mungkin diadopsi di Indonesia dengan berbagai penyesuaian. Pelaksanaan program serupa diharapkan dapat membantu mengurangi penggunaan antibiotik swamedikasi di Indonesia.

Hasil lain terkait perilaku penggunaan antibiotik tanpa resep dokter dalam penelitian ini yang perlu mendapat perhatian adalah terdapat $11,98 \%$ pasien yang menggunakan antibiotik sisa resep dokter sebelumnya untuk swamedikasi antibiotik. Perilaku tersebut juga ditemukan dalam bukti penelitian terpublikasi yang lain. Grigoriyan et al. juga menunjukkan bahwa riwayat penggunaan antibiotik dengan resep dokter dalam 1 tahun sebelumnya, meningkatkan risiko swamedikasi dengan antibiotik sisa pengobatan (leftover antibiotics). ${ }^{29}$ Fenomena swamedikasi dengan menggunakan antibiotik sisa dari resep sebelumnya juga dapat menandakan kurangnya kepatuhan pasien dalam menggunakan antibiotik. Sebuah bukti penelitian terpublikasi menunjukkan fenomena ketidakpatuhan penggunaan antibiotik. Hasil penelitian oleh Suaifan et al. terhadap 679 responden mahasiswa di Yordania yang menunjukkan bahwa $61,20 \%$ responden tidak menyelesaikan penggunaan antibiotik sesuai durasi yang seharusnya, 5,50\% responden mengurangi dosis antibiotik tanpa berkonsultasi ke dokter, dan $11,20 \%$ responden menghentikan penggunaan antibiotik tanpa berkonsultasi ke dokter. ${ }^{30}$ Alasan terbesar responden tidak menyelesaikan penggunaan antibiotik sesuai anjuran dokter adalah responden telah merasa lebih baik $(59,10 \%)$ dan lupa atau tidak punya waktu $(14,30 \%){ }^{30}$ Penelitian lebih lanjut terkait kepatuhan penggunaan antibiotik dengan setting Indonesia perlu dilakukan untuk mendapatkan gambaran utuh dari fenomena perilaku swamedikasi dengan antibiotik sisa pengobatan.

Sebanyak 65 pasien $(24,34 \%)$ menggunakan antibiotik tanpa resep dokter karena disarankan oleh teman/kerabat yang bekerja di bidang kesehatan dan hanya satu orang $(0,38 \%)$ yang menggunakan antibiotik karena disarankan oleh orang penting di desa. Hasil penelitian ini mempertegas 
besarnya pengaruh lingkungan sekitar dalam menentukan sebuah perilaku. Bukti penelitian yang dilakukan di negara lain menunjukkan besarnya pengaruh apoteker dalam perilaku penggunaan antibiotik tanpa resep dokter. ${ }^{31}$ Perbedaan antara hasil penelitian ini dan penelitian di negara lain dapat dipicu oleh perbedaan kultur dan budaya yang ada di negara-negara tersebut yang menyebabkan perbedaan model interaksi masyarakatnya. Besarnya perilaku penggunaan yang didasarkan pada saran kerabat dalam penelitian ini mempertegas model masyarakat Indonesia yang sangat komunal. Salah satu ciri masyarakat komunal adalah kepercayaan terhadap kerabat yang sangat kuat, bahkan melebihi kepercayaan terhadap tenaga kesehatan.

Antibiotik dalam penelitian ini digunakan oleh pasien untuk mengatasi indikasi pilek/flu (57 pasien/21,35\%), demam (53 pasien/19,85\%) dan batuk (47 pasien/17,60\%). Beberapa penelitian terpublikasi juga menegaskan beberapa gejala tersebut menjadi penyebab utama pasien membeli antibiotik tanpa resep dokter. ${ }^{31,32}$ Penggunaan antibiotik untuk flu dan diare merupakan praktek penggunaan antibiotik untuk indikasi yang kurang tepat. Flu dan diare umumnya disebabkan oleh virus, bukan bakteri, sehingga tidak memerlukan terapi antibiotik. Selain tidak diperlukan, penggunaan antibiotik tanpa resep dokter juga berpotensi menyebabkan penundaan pemeriksaan diri ke dokter yang pada akhirnya akan menempatkan pasien pada risiko tertinggi mengalami kegagalan diagnosis kemungkinan adanya penyakit yang serius, seperti tuberculosis. ${ }^{33}$

Hasil analisis deskriptif terkait faktor dominan yang menyebabkan perilaku penggunaan antibiotik tanpa resep menunjukkan domain "halhal yang mendorong" yang dalam penelitian ini meliputi pengalaman penggunaan antibiotik sebelumnya, perilaku peresepan dokter, dan akses untuk memperoleh antibiotik sebagai faktor utama penyebab perilaku tersebut. Pengalaman penggunaan antibiotik sebelumnya sebagai faktor dominan menentukan perilaku penggunaan antibiotik tanpa resep dokter juga ditemukan dalam penelitian Khan et al. di India yang menunjukkan bahwa $56,50 \%$ pasien melakukan swamedikasi antibiotik karena telah menggunakan antibiotik sebelumnya. ${ }^{9}$ Penelitian lain oleh Shah et al. di Pakistan juga menunjukkan bahwa 33,00\% menggunakan antibiotik tanpa resep karena telah sukses menggunakan antibiotik tanpa resep dokter pada pengobatan sebelumnya ${ }^{34}$ Besarnya dominasi faktor pengalaman yang ditemukan dalam penelitian ini dan beberapa penelitian terpublikasi lainnyadapat dijelaskan dengan teori perilaku kesehatan. Dilihat dari kerangka Theory of Planned Behavior (TPB), pengalaman penggunaan antibiotik tanpa resep dokter sebelumnya dapat membentuk kepercayaan terhadap hasil perilaku (beliefs about outcome) yang nantinya akan mempengaruhi sikap pasien terhadap perilaku penggunaan antibiotik tanpa resep dokter (attitude towards behavior). ${ }^{35}$

Aspek kedua yang diklasifikasikan dalam kategori "hal-hal yang mendorong" perilaku pembelian antibiotik tanpa resep dokter dalam penelitian ini adalah perilaku peresepan dokter. Penelitian terpublikasi lain juga menunjukkan dominasi faktor peresepan dokter terhadap pembelian antibiotik tanpa resep dokter. ${ }^{36}$ Pola peresepan dokter merupakan salah satu pengejawantahan "subjective norm" dari TPB yang berarti perilaku orang-orang yang dianggap penting oleh masyarakat menentukan perilaku kesehatan dari masyarakat tersebut. Besarnya peresepan antibiotik untuk penyakit dengan gejala tertentu diidentifikasi oleh masyarakat sebagai suatu pola umum peresepan yang kemudian dapat disalah artikan implementasinya dalam kehidupan sehari-hari. Tidak dapat dipungkiri, tingginya peresepan antibiotik oleh dokter di komunitas juga disebabkan tidak tersedianya metode atau alat diagnostik yang dapat membantu menetapkan mikroorganisme yang menyebabkan infeksi secara cepat dan tepat. ${ }^{37}$ Kultur yang ada saat ini mampu mendeteksi mikroorganisme penyebab infeksi dalam waktu minimal 3 hari, sehingga kurang aplikatif dalam praktek sehari-hari. Lamanya waktu yang dibutuhkan untuk mendapatkan hasil kultur menyebabkan dokter memilih untuk meresepkan antibiotik untuk alasan keselamatan pasien. Oleh karena itu, diperlukan pengembangan suatu alat uji diagnostik yang dapat mendeteksi mikroorganisme penyebab infeksi secara cepat dan tepat. Inovasi ini diharapkan dapat mengurangi penggunaan antibiotik yang tidak perlu, sehingga secara tidak langsung turut mengurangi penggunaan antibiotik tanpa resep dokter di apotek.

Hasil analisis faktor dalam penelitian ini 
selaras dengan hasil analisis deskriptif dan mempertegas faktor yang dominan mempengaruhi perilaku pembelian antibiotik tanpa resep di apotek, yaitu faktor kemudahan akses memperoleh antibiotik dan faktor penghematan biaya dengan percent of variance explained sebesar 23,91\%. Dominasi faktor kemudahan akses memperoleh antibiotik dan faktor penghematan biaya dalam menentukan perilaku penggunaan antibiotik secara swamedikasi juga ditemukan dalam penelitian Yu et al. pada tahun 2014 di Cina. Kemudahan akses memperoleh antibiotik menjadi faktor yang menjadi alasan $19,00 \%$ orang tua di perkotaan dan $12,00 \%$ orang tua di pedesaan untuk melakukan swamedikasi antibiotik pada anak. ${ }^{38}$ Penelitian terpublikasi lain oleh Donkor et al. terhadap 422 pelajar di Ghana juga menunjukkan bahwa $40,50 \%$ pasien melakukan swamedikasi antibiotik karena biaya yang lebih murah dan menghindari lamanya waktu yang dibutuhkan untuk memperoleh obat di pusat layanan kesehatan. ${ }^{36}$

Penelitian ini memiliki keterbatasan yakni faktor penyebab penggunaan antibiotik tanpa resep dokter yang tidak dapat digeneralisasikan pada seluruh wilayah Indonesia khususnya daerah dengan budaya yang lain. Hal ini dinyatakan dengan mempertimbangkan bahwa budaya memiliki pengaruh dalam menentukan perilaku seseorang termasuk perilaku kesehatan, dalam hal ini adalah pembelian antibiotik tanpa resep. ${ }^{39}$ Selain itu, generalisasi hasil penelitian ini terhadap individu yang tidak memiliki kemampuan membaca dan menulis (illiterate) tidak dapat dilakukan karena tidak terdapat kelompok tersebut yang terlibat sebagai responden. Penelitian lebih lanjut terhadap kelompok masyarakat dengan budaya yang berbeda dan masyarakat yang tidak memiliki kemampuan membaca dan menulis perlu dilakukan untuk mengetahui perilaku dan faktor penyebab perilaku penggunaan antibiotik tanpa resep pada kelompok khusus tersebut.

\section{KESIMPULAN DAN SARAN}

Berdasarkan hasil penelitian ini, disimpulkan bahwa penggunakan antibiotik yang didapatkan tanpa resep dokter di Surabaya sebagian besar dilakukan oleh kelompok masyarakat usia produktif untuk mengobati gejala yang umumnya disebabkan oleh patogen non-bakteri. Faktor yang paling mempengaruhi perilaku pembelian antibiotik tanpa resep dokter dalam penelitian ini adalah kemudahan akses untuk memperoleh antibiotik di apotek. Kontrol pemerintah berupa implementasi regulasi yang lebih ketat merupakan salah satu pendekatan intervensi yang diharapkan dapat menutup akses penggunaan antibiotik tanpa resep dokter yang demikian luas terjadi di Indonesia. Namun demikian, pendekatan secara tegas melalui pembuatan kebijakan terhadap akses pembelian antibiotik di komunitas, tidak akan membuahkan hasil yang optimal apabila tidak disertai dengan perubahan perilaku tenaga kesehatan. Penelitian lebih lanjut terkait perilaku penjualan antibiotik tanpa resep dokter oleh petugas apotek dan faktor yang mempengaruhi perilaku tersebut perlu dilakukan. Intervensi terhadap aktor pelaku pembelian dan penjualan antibiotik tanpa resep secara holistik diharapkan dapat memberikan dampak secara signifikan terhadap penurunan perilaku penggunaan antibiotik yang tidak bertanggung jawab di komunitas.

\section{DAFTAR PUSTAKA}

1. National Center for Health Statistics. National Hospital Ambulatory Medical Care Survey: 2010 Outpatient Department Summary Tables. Hyattsvile, MD; 2010.

2. National Center for Health Statistics. National Ambulatory Medical Care Survey: 2009 Summary Tables. Hyattsvile, MD; 2009.

3. WHO Collaborating Centre for Drug Statistics Methodology. Guidelines for ATC Classification and DDD Assignment 2013. Oslo; 2012.

4. European Centre for Disease Prevention and Control. Surveillance of Antimicrobial Consumption in Europe 2010. Stockholm: ECDC; 2013.

5. Al-faham Z, Habboub G, Takriti F. The sale of Antibiotics without Prescription in Pharmacies in Damascus, Syria. J Infect Dev Ctries. 2011;5(5):369-99.

6. Plachouras D, Kavatha D, Antoniadou A, Giannitsioti E, Poulakou G, Kanellakopoulou K, et al. Dispensing of Antibiotics without Prescription in Greece. 2008: Another Link in the Antibiotic Resistance Chain. Euro Surveill. 2010;15(7):4-7.

7. Bin Abdulhak AA, Altannir MA, Almansor 
MA, Almohaya MS, Onazi AS, Marei MA, et al. Non Prescribed Sale of Antibiotics in Riyadh, Saudi Arabia: a cross sectional study. BMC Public Health. 2011;11(1):538.

8. Llor C, Cots JM. The Sale of Antibiotics without Prescription in Pharmacies in Catalonia, Spain. Clin Infect Dis. 2009;48(10):1345-9.

9. Khan SJ, Khan S, Shah N, Complex HM. Self Medication with Antibiotics in Urban Areas of Peshawar. Gomal Journal of Medical Sciences. 2011;9(1):2009-12.

10. Abasaeed A, Vlcek J, Abuelkhair M, Kubena A. Self Medication with Antibiotics by the Community of Abu Dhabi Emirate, United Arab Emirates. J Infect Dev Ctries. 2009;3(7):491-7.

11. Widayati A, Suryawati S, de Crespigny C, Hiller JE. Self Medication with Antibiotics in Yogyakarta City Indonesia: a Cross Sectional Population Based Survey. BMC Res Notes. 2011;4:491.

12. Skalet AH, Cevallos V, Ayele B, Gebre T, Zhou Z, Jorgensen JH, et al. Antibiotic Selection Pressure and Macrolide Resistance in Nasopharyngeal Streptococcus Pneumoniae: a Cluster Randomized Clinical trial. PLoS Med. 2010;7(12):e1000377.

13. Hicks LA, Chien YW, Taylor TH, Haber M, Klugman KP. Outpatient Antibiotic Prescribing and Non-Susceptible Streptococcus Pneumoniae in the United States, 1996-2003. Clin Infect Dis. 2011;53(7):631-9.

14. Tan SK, Tay YK. Profile and Pattern of Stevens-Johnson Syndrome and Toxic Epidermal Necrolysis in a General Hospital in Singapore: Treatment Outcomes. Acta Derm Venereol. 2012;92(1):62-6.

15. Durrieu G, Maupiler M, Rousseau V, Chebane L, Montastruc F, Bondon-Guitton E, et al. Frequency and Nature of Adverse Drug Reactions Due to Non-Prescription Drugs in Children: a Retrospective Analysis from the French Pharmacovigilance Database. Paediatr Drugs. 2018;20(1):81-7.

16. Emeka PM, Al-Omar MJ, Khan TM. A Qualitative Study Exploring Role of Community Pharmacy in the Irrational Use and Purchase of Non-Prescription Antibiotics in Al Ahsa. EurJ Gen Med. 2012; 9(4):230-4.
17. Hadi U, van den Broek P, Kolopaking EP, Zairina N, Gardjito W, Gyssens IC. Cross Sectional study of Availability and Pharmaceutical Quality of Antibiotics Requested with or without Prescription (Over the Counter) in Surabaya, Indonesia. BMC Infect Dis. 2010;10:203.

18. Nga do TT, Chuc NT, Hoa NP, Hoa NQ, Nguyen NT, Loan HT, et al. Antibiotic Sales in Rural and Urban Pharmacies in Northern Vietnam: an Observational Study. BMC Pharmacol Toxicol. 2014;15:6.

19. Zoorob R, Grigoryan L, Nash S, Trautner BW. Non Prescription Antimicrobial Use in a Primary Care Population in the United States. Antimicrob Agents Chemother. 2016;60(9):5527-32.

20. World Health Organization. Antimicrobial Resistance. WHO Web Sites; 2014 [cited 2016 Apr 20]; Available from: http://www.who.int/ mediacentre/factsheets/fs 194/en/.

21. Centers for Disease Control and Prevention. Antibiotic Resistance Threats in the United States, 2013. U.S. Department of Health and Human Services Web Sites; 2013 [cited 2016 Apr 20]; Available from: https://www.cdc. gov/drugresistance/pdf/ar-threats-2013-508. pdf.

22. Djawaria DPA, Prayitno A, Setiawan E.Pengembangan dan Validasi Kuesioner untuk Mengidentifikasi Faktor Penyebab Perilaku Penggunaan Antibiotik tanpa Resep Dokter. Jurnal Ilmu Kefarmasian Indonesia. 2018;16(1):107-114.

23. Notoadmojo S. Metodologi Penelitian Kesehatan Edisi Revisi. Jakarta: PT. Rineka Cipta; 2005.

24. Puspitasari HP, Faturrohmah A, Hermansyah A. Do Indonesian Community Pharmacy Workers Respond to Antibiotics Requests Appropriately?. Trop Med Int Health. 2011;16(7):840-6.

25. Bin Nafisah S, Bin Nafesa S, Alamery AH, Alhumaid MA, AlMuhaidib HM, Al-Eidan FA.Over the Counter Antibiotics in Saudi Arabia, an Urgent Call for Policy Makers. J Infect Public Health. 2017;10(5):522-6.

26. Widayati A, Suryawati S, de Crespigny C, Hiller JE. Beliefs about the Use of Non Prescribed Antibiotics among People in Yogyakarta City, 
Indonesia: a Qualitative Study Based on the Theory of Planned Behavior. Asia PacJ Public Health. 2015;27(2):NP402-13.

27. Sabuncu E, David J, Bernede-Bauduin C, Pepin S, Leroy M, Boelle PY, et al. Significant Reduction of Antibiotic Use in the Community after a Nationwide Campaign in France, 2002-2007. PLoS Med. 2009;6(6):e1000084.

28. Sumpradit N, Chongtrakul P, Anuwong K, Pumtong S, Kongsomboon K, Butdeemee P, et al. Antibiotics Smart Use: a Workable Model for Promoting the Rational Use of Medicines in Thailand. Bull World Health Organ. 2012;90(12):905-13.

29. Grigoryan L, Monnet DL, Haaijer-Ruskamp FM, Bonten MJ, Lundborg S, Verheij TJ. Self Medication with Antibiotics in Europe: a case for action. Curr Drug Saf. 2010;5(4):329-32.

30. Suaifan GARY, Shehadeh M, Darwish DA, Al-ijel H, Yousef AM, Darwish RM. A Cross Sectional Study on Knowledge, Attitude and Behavior Related to Antibiotic Use and Resistance among Medical and Non Medical University Students in Jordan. Afr J Pharm Pharmacol. 2012;6(10):763-70.

31. Belkina T, Al Warafi A, Hussein Eltom E, Tadjieva N, Kubena A, Vicek J. Antibiotic Use and Knowledge in the Community of Yemen, Saudi Arabia, and Uzbekistan. J Infect Dev Ctries. 2014;8(4):424-9.

32. Fadare JO, Tamuno I. Antibiotic Self Medication among University Medical Undergraduates in Northern Nigeria. JPublic Health Epidemiol. 2011;3(5):217-20.
33. Belkina TV, Khojiev DS, Tillyashaykhov MN, Tigay ZN, Kudenov MU, Tebbens JD, et al. Delay in the Diagnosis and Treatment of Pulmonary Tuberculosis in Uzbekistan: a Cross Sectional Study. BMC Infect Dis. 2014;14:624.

34. Shah SJ, Ahmad H, Rehan RB, Najeeb S, Mumtaz M, Jilani MH, et al. Self Medication with Antibiotics among Non-Medical University Students of Karachi: a Cross-Sectional Study. BMC Pharmacol Toxicol. 2014;15:74.

35. Ogden J. Health Beliefs. Health Psychology. 4th ed. New York: Open University Press; 2007.

36. Donkor ES, Tetteh-quarcoo PB, Nartey P, Agyeman IO. Self-Medication Practices with Antibiotics among Tertiary Level Students in Accra, Ghana: a Cross-Sectional Study. Int J Environ Res Public Health. 2012;9(10): 351929.

37. Bebell LM, Muiru AN. Antibiotic Use and Emerging Resistance How Can Resource Limited Countries Turn the Tide?. Glob Heart. 2014;9(3):347-58.

38. Yu M, Zhao G, Staisby Lundborg C, Zhu Y, Zhao Q, Xu B. Knowledge, Attitudes, and Practices of Parents in Rural China on the Use of Antibiotics in Children: a Cross-Sectional Study. BMC Infect Dis. 2014;14:112.

39. Levesque A, Li HZ. The Relationship between Culture, Health Conceptions, and Health Practices: a Qualitative-Quantitative Approach. J Cross Cult Psychol. 2014;45(4):628-45. 